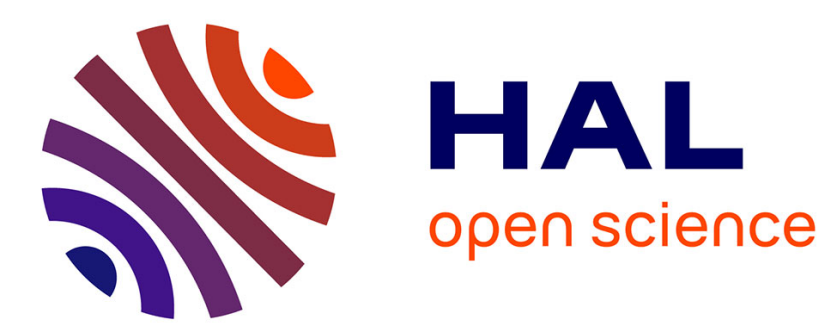

\title{
SECTORAL EFFECTS OF MONETARY POLICY: EVIDENCE FROM MOROCCO
}

Charaf Eddine Moussir, Abdellatif Chatri

\section{To cite this version:}

Charaf Eddine Moussir, Abdellatif Chatri. SECTORAL EFFECTS OF MONETARY POLICY: EVIDENCE FROM MOROCCO. Finance et Finance Internationale, 2017, 6. hal-01449475

\section{HAL Id: hal-01449475 \\ https://hal.science/hal-01449475}

Submitted on 3 Feb 2017

HAL is a multi-disciplinary open access archive for the deposit and dissemination of scientific research documents, whether they are published or not. The documents may come from teaching and research institutions in France or abroad, or from public or private research centers.
L'archive ouverte pluridisciplinaire HAL, est destinée au dépôt et à la diffusion de documents scientifiques de niveau recherche, publiés ou non, émanant des établissements d'enseignement et de recherche français ou étrangers, des laboratoires publics ou privés. 


\title{
SECTORAL EFFECTS OF MONETARY POLICY: \\ EVIDENCE FROM MOROCCO
}

\author{
Par \\ Charaf-Eddine MOUSSIR \\ Chercheur à la FSJES de Rabat- Agdal, Université Mohammed V- Rabat.
}

\&

\begin{abstract}
Abdellatif CHATRI
Professeur d'Economie Monétaire et Financière, FSJES de Rabat-Agdal, Université Mohammed V -Rabat.
\end{abstract}

Résumé

L'objectif de cet article est de mettre en lumière l'existence de différences significatives dans les réactions des secteurs marocains aux chocs de politique monétaire. Les résultats de l'analyse indiquent que, au niveau agrégé un resserrement de la politique monétaire conduit à une diminution du niveau du PIB et du niveau des prix. Au niveau désagrégé, l'industrie d'extraction, de manufacture, le BTP, hôtels et restaurants, les activités financières et d'assurance sont parmi les secteurs les plus sensibles aux chocs de politique monétaire. D'autre part les innovations de la politique monétaire ne semblent pas avoir un impact significatif sur les secteurs de l'agriculture et de la pêche.

Mots clés

Politique monétaire; Production sectorielle; Modèle VAR; Fonctions de réponse impulsionnelle ; Maroc.

\section{Abstract}


The purpose of this paper is to shed more light on the existence of significant differences in the reactions of Moroccan sectors to monetary policy shocks. The results of the analysis indicate that at the aggregate level a monetary policy tightening leads to a decrease of the overall GDP and price level. At the disaggregated level, the extraction industry, manufacturing, construction, hotels \& restaurants, the financial and insurance activities are among the more sensitive sectors to monetary policy shocks. On the other hand monetary policy innovations do not appear to have an adverse impact on agriculture and fishing sectors.

\section{Keywords}

Monetary policy, sectoral output, VAR model, Impulse response functions; Morocco. 


\section{$1 \quad$ Introduction}

The effects of monetary policy on economic performance have long attracted the attention of economists and policy makers. In recent years, there seems to be a growing consensus among economists that monetary policy has an impact on the real economy, at least in the short term. The literature shows that monetary policy can have negative effects on sectoral growth and consequently on overall growth and that; different sectors of the economy react differently to monetary policy shocks (Serju 2003; Alam and Waheed 2006 ; Dal 2011). Therefore, it is necessary to know the sectors that respond first to a monetary policy shock and if the effects could be more important in some sectors than in others. This may provide pertinent information for economic policy purposes (Ganley and Salmon 1997).

The empirical evidence on how the sectors react to monetary policy shocks is relevant about how to stimulate growth. Indeed, studies of sectoral analysis of the transmission channels of monetary policy in developing countries, in particular, indicate that tight monetary policy negatively affects agriculture and manufacturing, which are considered as the primary growth sectors for most developing economies (Serju 2003; Ifeanyichukwu and Olufemi 2012).

Our goal in this article is to highlight the disaggregated effect of the transmission of monetary policy in Morocco. Specifically, we want to shed more light on the existence of significant differences in the reactions of Moroccan sectors to monetary policy shocks. The organization of this paper is as follows. In Section 2, we give a review of the theoretical literature, and the main results of the various studies that have attempted to highlight the sectoral effects of a tightening monetary policy, while in Section 3 we present the data and the estimation method. In Section 4 we discuss the results and conclude in Section 5.

\section{Background information}

The monetary transmission mechanism can be defined as the channel through which changes in the money supply affect the decisions of firms, households, financial intermediaries, investors and modify the level of economic activity and prices (Mishikin 1995 ; Kuttner 2001). The literature identifies different ways of understanding the monetary transmission 
mechanisms ${ }^{1}$. They vary according to the importance given to interest rates, credits, exchange rates, asset prices and other financial institutions in the transmission mechanism (Mishkin 1995). According to this author an expansionary monetary policy, through the channel of interest rate causes a decline in real interest rate, leading to lower cost of the capital. The decrease pushes economic agents to increase their investment spending, which could lead to an increase in aggregate demand and, consequently, the level of overall production.

In addition to that, the literature highlighted that the bank lending channel, which is a complementary channel to the interest rate, plays an important role in the transmission of monetary policy. A tightening of monetary policy reduces the reserves of the bank and its deposits, which limits the amount of the bank loans available to borrowers. This ultimately reduces the private investment and the output (Bernanke and Gertler 1995).

As for the channel of interest rate, an expansionary monetary policy leads to a lower real interest rate, resulting in a depreciation of the national currency and therefore a decline in the exchange rate. This depreciation results in an increase in net exports and thus in the overall production.

Another potential conduit of monetary policy shocks is fluctuations in asset price. An expansionary monetary policy can boost equity prices by making equity relatively more attractive to bonds. This monetary easing can also as improve the earnings outlook for firms. A higher equity prices increases the market value of firms relative to the replacement cost of capital (the Tobin's q). Secondly, increases in stock prices translate into higher financial wealth of households and therefore higher consumption (Boughrara 2009).

There is interest among researchers and policy makers in the effects of transmission of monetary policy on the real economy. Paradoxically, few works have focused on the study of the impact of transmission channels of monetary policy on aggregate growth by sector, even less for developing economies. The changes in monetary shocks on different sectors can occur due to the importance of a particular channel of the transmission mechanism for certain sectors and not for others. This relative intensity, in turn, depends crucially on the structure, the dependency and the availability of the bank credit, and the opening of a particular sector.

\footnotetext{
${ }^{1}$ This is a brief survey of monetary policy transmission mechanisms. For details, see: Mishkin, F.S. (1995). The Channels of Monetary Transmission: Lessons For Monetary Policy . National Bureau Of Economic Research, Working Paper 5464.
} 
A first attempt to explore the monetary transmission at the disaggregated level was undertaken by Bernanke and Gertler (1995). In order to do so, they used a vector auto regression model (VAR) to identify the different impacts of monetary policy on the components of final expenditure. Ganley and Salmon (1997) compared the response of output to monetary shock in nine major sectors. For that purpose, they estimate for each industrial sector a vector error correction model VECM that includes the interest rate, the overall GDP, the GDP deflator, and sectoral output. Among the nine major sectors, they find out that the construction, distribution, transportation and manufacturing have the most significant reactions to a monetary shock. Government, financial services and public services respond relatively weakly to the impact. The reaction of the mining sector is somehow ambiguous while the agricultural sector's is insignificant.

Studies in other economies show that monetary policy has indeed significant and various impacts on different sectors of the economy. Ifeakachukwu and Olufemi (2012) use a VAR model to analyze the impact of monetary policy on the Nigerian economy at multisectoral level. The results of their study show that the sectors of agriculture and industry are most affected by interest rates, while other sectors such as construction, mining and wholesale trade are more affected by exchange rate shocks. The study also concludes that the stimulation of sectoral growth in Nigeria is due to the interest rate and exchange rate policies.

Cardia and Murcia (2004) use a Dynamic Stochastic General Equilibrium (DSGE) to analyze the transmission of monetary policy in a multi-sector economy. Their results show that the construction and capital goods industry are highly sensitive to a tightening monetary policy. These results confirm Serju's (2003) conclusion which reveal that the industrial sector has a larger and quicker decline as a response to an interest rate shock in Jamaica. In addition to that, Ilker (1999), using a VAR method, has found that small industries are more affected by interest rate shocks while large industries are submitted to exchange rate shocks.

Sahinoz and Cosar (2009) based their study on a VAR model to analyze the response of the Turkish industrial production to a monetary policy shock. Their results show that the industry responds largely to a monetary policy shock through the exchange rate. A restrictive monetary policy discourages growth in various sectors of the economy. Using the same method, Karim 
et al (2006) suggest that the negative impact of the tight monetary policy has a more important impact on agriculture, industry and mining in Malaysia.

\section{$3 \quad$ Data and estimation strategy}

As mentioned in previous studies on the transmission of monetary policy (Nampewo et al 2013; Alam and Waheed (2006); Ibrahim 2005), we use a VAR model (Vector autoregression) to estimate the sectoral responses of a tightening monetary policy.

The chosen model is analogous to Sims (1992). Equation (1) is written as follows:

$$
A x_{t}=B(L) L x_{t}+\varepsilon_{t}
$$

Where $x_{t}$ is the vector of endogenous variables, $A$ is a matrix of size $(\mathrm{n}, \mathrm{n})$ representing the relations of simultaneity between variables in $x_{t} \cdot \varepsilon_{t}$ is the vector of structural shocks, which are assumed to be normally and independently and identically distributed. They are also orthogonal. To capture the impact of monetary policy variable shocks on sectoral output, a VAR model is estimated from the reduced form VAR .Equation (2) clarifies this issue.

$$
y_{t}=A_{0}^{-1} B(L) y_{t}+A_{0}^{-1} u_{t}
$$

This form can also be written in equation (3) in the form of moving average:

$y_{t}=C(L) \varepsilon_{t} ;$ Where $C(L)=\left(I-A_{0}^{-1} B(L)\right)^{-1}$ et $\varepsilon_{t}=A_{0}^{-1}-u_{t}$

The data used in this study are quarterly, covering from 1998Q1 to 2014Q4. According to various studies, our model includes sectoral output (S) collected from Bank Al -Maghrib (BAM), the level of prices (cpi), the aggregate production (gdp) and a measure of monetary policy (M_p) collected from International Financial Statistics (IFS). We focus on eight different sectors in the analysis:

(S1): Agriculture

(S2): Fishing

(S3): Industry extraction

(S4): Manufacturing
(S5): construction and public works

(S6): Commerce

(S7): Hotels and restaurants

(S8): Financial and insurance activities 
The results of the unit root tests (ADF) indicate that the model variables are stationary in first difference $^{2}$. Moreover, the AR graph $^{3}$ also indicates that the roots lie within the unit circle. This confirms the stability of the VAR model.

Figure 1: GDP Growth and Inflation rate

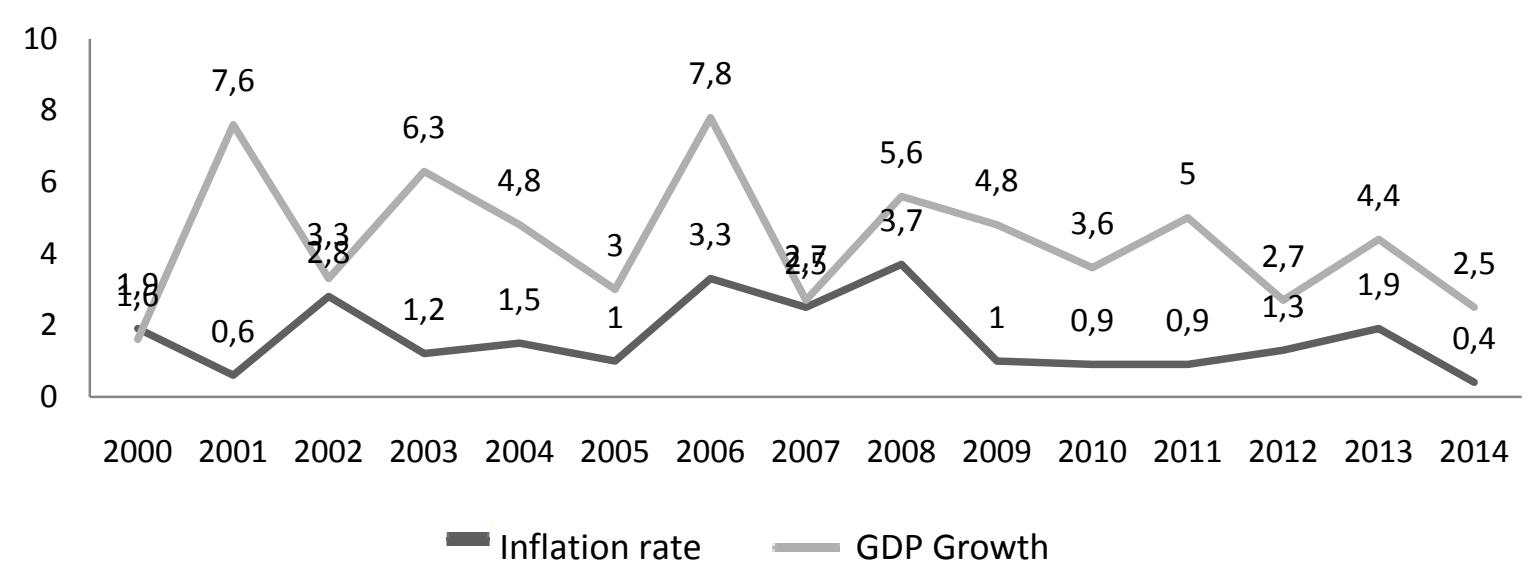

The figure 1 shows the rate of economic growth and inflation over the period 2000 - 2014. We note that fluctuations of the national economic growth start to wane from 2007 to fluctuate around $4.1 \%$. This is due, for the most part, the decline in the share of agriculture in GDP and the sustained performance of the industrial sector. Inflation for its part remained stable over this period, fluctuating around $1.2 \%$ except for 2002 when it was $2.8 \%$, a result of the stock market crash Internet bubble, and for the years 2006, 2007 and 2008 when it reached $3.7 \%$ in 2008 , due to the effects of the subprime crisis.

\footnotetext{
2 See appendix 1.

${ }^{3}$ See appendix 2.
} 
Figure 2: Average contribution to Real GDP(\%)

(1998Q1-2014Q4)

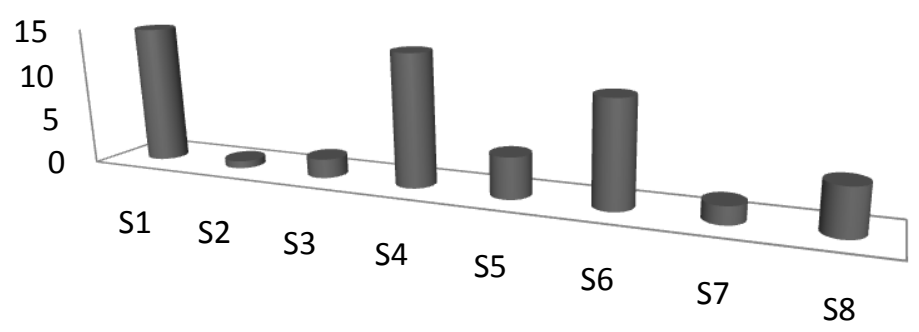

\begin{tabular}{|c|c|c|c|c|c|c|c|c|}
\cline { 2 - 9 } \multicolumn{1}{c|}{} & S1 & S2 & S3 & S4 & S5 & S6 & S7 & S8 \\
\hline — Série1 & 14,876084 & 0,7883976 & 2,0500832 & 14,188503 & 4,4152750 & 11,248899 & 1,8895521 & 4,9763735 \\
\hline
\end{tabular}

Figure 2 shows the average contribution of the eight sectors to real GDP between 1998Q1and 2014Q4. The agriculture, manufacturing and commerce sectors were the largest sectors, contributing approximately 14.87 per cent, 14.18 per cent and 11.24 per cent of GDP, respectively, over the period. Financial \& insurance activities and construction $\&$ public works approximately 4.97 per cent and 4.41 of GDP. Hotels and restaurants, Industry extraction and Fishing contributed the least, accounting for 1.89 per cent, 2.05 per cent and 0.79 per cent of GDP.

\section{$4 \quad$ Estimation results}

The impulse response analysis revealed several observations ${ }^{4}$. At the aggregate level, the effect of a tighter monetary policy leads to an instantaneous reduction in GDP, but temporarily bouncing between the second and third quarter. The rebound seems to imitate the responses of agriculture and construction during this period. There is an overall reduction in GDP in response to monetary shock after the third quarter. The impact of interest rates has a clear and negative incidence on the real economy in the short term before getting back to its steady state. The price level shows a raise down in responding to a positive shock on the interest rate in the $2^{\text {nd }}$ quarter, reaching its steady state in the $6^{\text {th }}$ quarter. This reaction agrees with the conventional view, considering that the price level decreases in response to positive shocks on interest rate.

\footnotetext{
${ }^{4}$ See appendix 3.
} 
The response of agriculture and fishing following a tightening monetary policy is observed on the 1 st and 3rd quarter respectively. This transitory behavior can be explained by the structure of these sectors, which depend on a traditional organization (family structure, low use of bank loans). The extraction and manufacturing industry have decreased due to an increase in the interest rate which is consistent with the theory. This immediate decline of production is a consequence of rising interest rates, considering the high dependence of the industrial sector on credits to finance their operations. The impact is dissipated starting from the $8^{\text {th }}$ quarter, and loses its intensity over time. Concerning the construction sector, there is an immediate decrease in production from the $1^{\text {st }}$ quarter but which dissipates from the $8^{\text {th }}$ quarter.

The impact of a monetary shock on the trade, hotels \& restaurants led to a sharp decline before converging towards their equilibrium levels at the end of the $7^{\text {th }}$ quarter. We also observe that the financial and insurance activities decline due to a rise in interest rates before rebounding in the $7^{\text {th }}$ quarter. The reaction is obvious because of the relationship between the central bank and commercial banks as a funding source, the reduction of the value added in the short term can be attributed to the decline in net interest margin of commercial banks in the context of a monetary shock, in other words the refinancing operations with the central bank becomes more expensive.

\section{Conclusion}

This paper investigates the sectoral effects of monetary policy in Morocco over the period 1998Q1 to 2014Q4 using a VAR model. The results of the analysis indicate that at the aggregate level a monetary policy tightening leads to a decrease of the overall GDP and price level. At the disaggregated level, monetary policy has disparate effects on the performance of the different sectors. The extraction industry, manufacturing, construction, hotels \& restaurants, the financial and insurance activities are among the more sensitive sectors to monetary policy shocks. On the other hand monetary policy innovations do not appear to have an adverse impact on agriculture and fishing sectors. This may be due the structure of these sectors, which depend on a traditional organization (family structure, low use of bank loans). The foregoing results imply that the interest rate channel plays significant role in the transmission process in the case of Morocco. 


\section{References}

Bank of England (2000), «The transmission mechanism of monetary policy », The Monetary Policy Committee.

Banque de France (2006), «La Politique Monétaire de l'Euro - système : Instruments et Procédures », Direction de la Communication, Note d'information $n^{\circ} 131$.

Bernanke, B.S., and M. Gertler (1995), «Inside the Black Box: The Credit Channel of Monetary Policy Transmission », Journal of Economic Perspectives - Volume 9, $\mathrm{n}^{\circ} 4, \mathrm{p}$. $27-48$.

Bernanke, B.S. \& Blinder A.S. (1988), «Credit, Money, and Aggregate Demand», The American Economic Review - Volume 78, n², p. 435 - 439.

Boughrara A. (2009), «Monetary Transmission Mechanisms in Morocco and Tunisia», Economic Research Forum.

Ganley J. \& Salmon C. (1997), «The Industrial Impact of Monetary Policy Shocks: Some Stylized Facts», Bank of England.

Hayo B. \& Uhlenbrock B. (1999), «Industry effects of monetary policy in Germany», Center for European Integration Studies.

Mishkin F.S. (1995), «The Channels of Monetary Transmission : Lessons For Monetary Policy », National Bureau Of Economic Research, Working Paper 5464.

Modigliani F. (1971), «'Monetary Policy and Consumption', in Consumer Spending and MonetaryPolicy: The Linkages », Boston: Federal Reserve Bank of Boston, p. 9-84

Nampewo D., Munyambonera E. \& Mayanja Lwanga M. (2013), «Sectoral Effects of Monetary Policy in Uganda», Journal of Empirical Economics.

Taylor J.B. (1995), « The Monetary Transmission Mechanism: An Empirical Framework », Journal of Economic Perspectives - Volume 9, n 4, p. $11-26$. 


\section{Appendix}

\section{Unit Root tests}

\begin{tabular}{|l|l|l|l|}
\hline Variables & In level & First difference & Conclusion \\
\hline MP & 0.3988 & 0.0001 & $\mathrm{I}(1)$ \\
\hline S1 & 0.7858 & 0.0000 & $\mathrm{I}(1)$ \\
\hline S2 & 0.7656 & 0.0255 & $\mathrm{I}(1)$ \\
\hline S3 & 0.1535 & 0.0000 & $\mathrm{I}(1)$ \\
\hline S4 & 0.6015 & 0.0000 & $\mathrm{I}(1)$ \\
\hline S5 & 0.6210 & 0.0000 & $\mathrm{I}(1)$ \\
\hline S6 & 0.7191 & 0.0000 & $\mathrm{I}(1)$ \\
\hline S7 & 0.1113 & 0.0000 & $\mathrm{I}(1)$ \\
\hline S8 & 0.8208 & 0.0001 & $\mathrm{I}(1)$ \\
\hline PIB & 0.3988 & 0.0001 & $\mathrm{I}(1)$ \\
\hline CPI & 0.1309 & 0.0000 & $\mathrm{I}(1)$ \\
\hline
\end{tabular}

\section{The AR test for model stability}

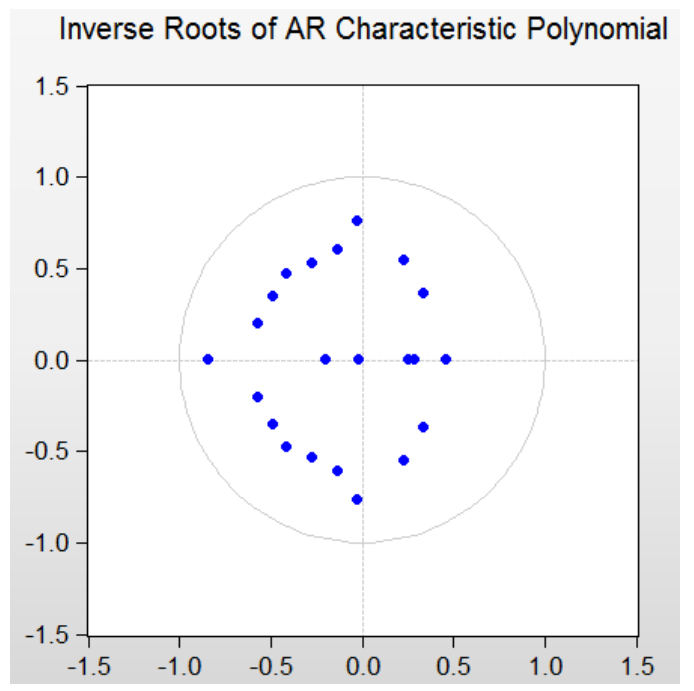


3. Impulse response functions
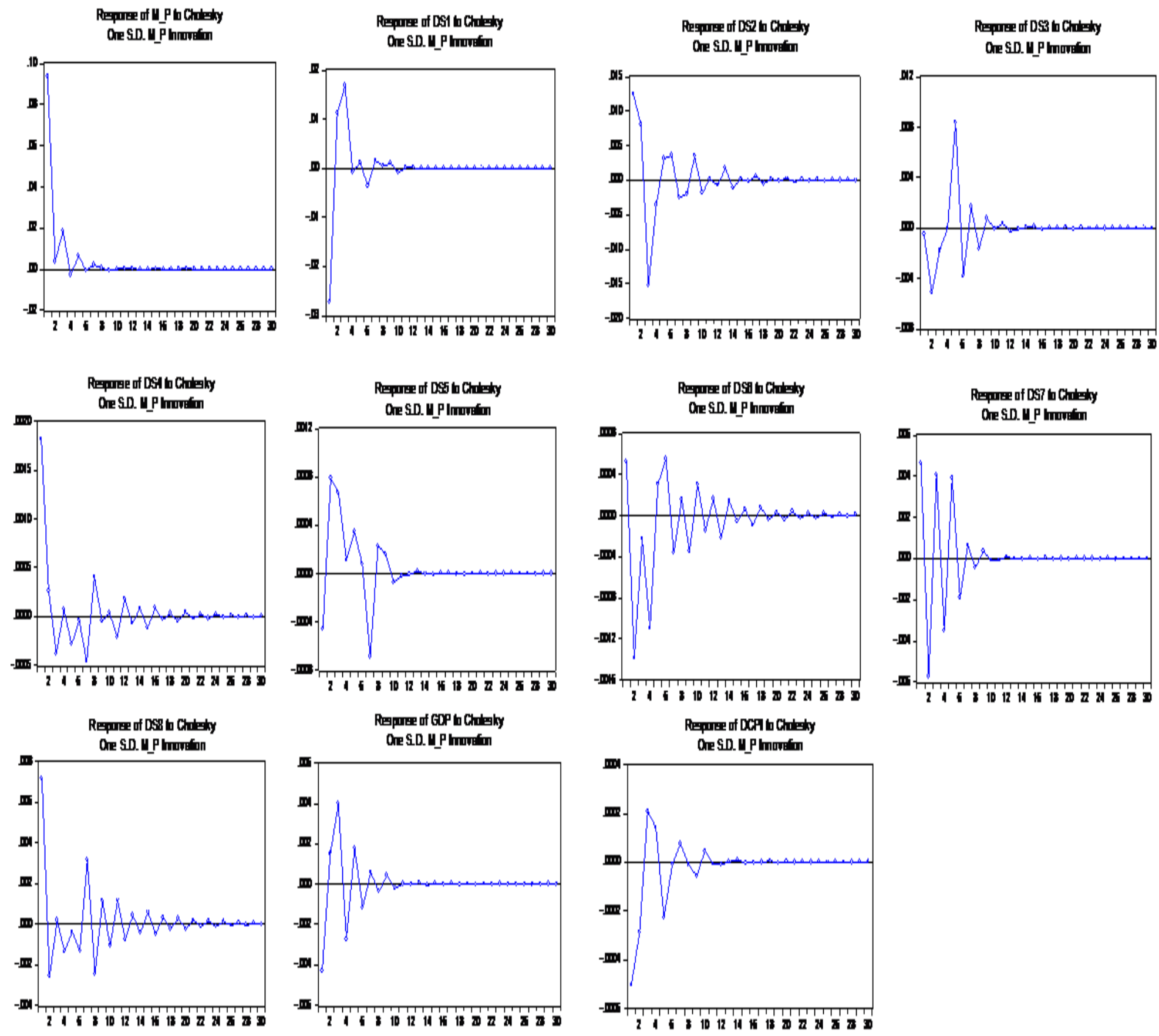